\title{
The exbD2 gene as well as the iron-uptake genes tonB, exbB and exbD1 of Xanthomonas campestris pv. campestris are essential for the induction of a hypersensitive response on pepper (Capsicum annuum)
}

\author{
Heinrich-G. Wiggerich and Alfred Pühler
}

\begin{abstract}
Author for correspondence: Alfred Pühler. Tel: +49 521106 5607. Fax: +49 5211065626. e-mail: alfred.puehler@genetik.uni-bielefeld.de
\end{abstract}

Lehrstuhl für Genetik, Fakultät für Biologie, Universität Bielefeld Postfach 100131, D-33501 Bielefeld, Germany

\begin{abstract}
The tonB, exbB and exbD1 genes of Xanthomonas campestris pv. campestris are essential for ferric iron uptake. In contrast, the exbD2 gene located in the same gene cluster is not essential. Mutational analysis revealed that the ferriciron-uptake genes ton $B$, exbB and exbD1 are necessary for the induction of a hypersensitive response (HR) on the nonhost plant pepper (Capsicum annuum) and the induction of typical black rot symptoms on the host plant cauliflower (Brassica oleracea). Again, the exbD2 gene behaved differently. It was found to play a role only in the induction of the HR in pepper but not in the induction of black rot symptoms in cauliflower. Due to the low iron concentration in the plant tissue, the titre of viable bacteria of the ferric-iron-uptake mutants tonB, exbB and exbD1 decreased after leaf infiltration of pepper. The exbD2 mutant, however, which is not impaired in ferric iron uptake, multiplied in the pepper leaf tissue and grew even better than the wild-type strain, probably due to its failure to induce the HR. Nevertheless, the tonB, exbB and exbD1 mutant strains were able to spread systemically in cauliflower.
\end{abstract}

Keywords: Xanthomonas campestris, Capsicum annuum, tonB, exbB, exbD

\section{INTRODUCTION}

Xanthomonas campestris pv. campestris is the causal agent of black rot disease of crucifers (Williams, 1980; Swings \& Civerolo, 1993). After infection of a plant with $X$. campestris pv. campestris, two different types of reactions can be observed depending on the susceptibility of the particular plant. If the plant is susceptible, the infection gives rise to blackening of leaf veins, followed by drying and death of the leaf tissue (compatible interaction). In contrast, a hypersensitive response $(\mathrm{HR})$ is induced in a resistant plant or a nonhost plant (incompatible interaction). The HR is a local defence response characterized by rapid tissue necrosis in the inoculated area (Klement, 1982). The $X$. campestris pv. campestris genes identified so far are of different importance in compatible and incompatible

Abbreviation: HR, hypersensitive response. interactions. Genes involved in protein secretion, production of protease, endoglucanase and polygalacturonate lyase (reviewed by Dow \& Daniels, 1994) and exopolysaccharide (EPS) synthesis (reviewed by Sutherland, 1993) have been identified. Mutants defective in the production of only one of these extracellular enzymes or EPS were still able to cause black rot. Therefore, the exact role of degradative enzymes and of EPS production in pathogenicity is unclear. Regulatory mutants that lack both extracellular enzymes and EPS do not induce disease symptoms on host plants, whereas the induction of the HR in nonhosts is not affected (Daniels et al., 1992).

The hrp genes (hypersensitive response and pathogenicity) are essential for virulence on host plants and for induction of a HR on nonhost plants. hrp genes have been identified in Pseudomonas syringae spp., Ralstonia solanacearum (formerly Pseudomonas solanacearum), Erwinia amylovora and $X$. campestris pathovars (Bonas, 1994; Willis et al., 1991). Several hrp gene 
products show sequence homology to proteins mediating the type III secretion of virulence factors from animal bacterial pathogens and are therefore predicted to be involved in the secretion of molecules essential for the interaction with the plant (Fenselau et al., 1992; Fenselau \& Bonas, 1995; Wengelnik et al., 1996). Hrpdependent secretion has been demonstrated for the harpin proteins of E. amylovora, Erwinia chrysanthemi and $P$. syringae pv. syringae and the PopA protein of $R$. solanacearum (Arlat et al., 1994; He et al., 1993; Wei et al., 1992).

Over 30 avirulence (avr) genes have been identified as essential for the HR in host and nonhost plants. In a gene-for-gene relationship, avirulence genes confer cultivar-specific interactions on resistant hosts as well as on nonhost plants (Dangl, 1994; Ritter \& Dangl, 1995). Members of the avirulence/pathogenicity gene family were shown to encode functional nuclear localization signals (Yang \& Gabriel, 1995). These proteins are therefore proposed to be translocated into the plant nucleus. Recently, the AvrBs3 protein from $X$. campestris pv. vesicatoria was shown to be recognized inside the plant cell and to require functional nuclear localization signals (Van den Ackerveken et al., 1996).

Moreover, iron is considered to play a crucial role in plant-phytopathogen interactions (Expert et al., 1996; Loper \& Buyer, 1991). Iron is one of the factors that limits bacterial growth in planta because micromolar concentrations of iron are necessary to support growth and multiplication. The common strategy of bacteria to overcome this problem is the utilization of siderophores with high affinity for ferric iron (Raymond et al., 1989). Ferric iron is complexed by these chelators, which are transported into the cell via an energy-coupled process mediated by the TonB system (reviewed by Braun, 1995). Outer-membrane receptors and the cytoplasmic membrane proteins $\mathrm{TonB}$ and ExbBD are involved in this process. In current models, the TonB protein induces a conformational change of the receptor proteins, which causes the release of bound ligands into the periplasmic space. Since the translocation into the periplasm is energy-dependent, TonB is considered to transduce the cytoplasmic membrane proton force to the receptor proteins (Bradbeer, 1993). Two auxiliary proteins, ExbB and ExbD, forming a complex with TonB, are necessary for TonB-dependent uptake. In addition to import processes across the outer membrane, the TonB system mediates signal transduction from the cell surface to the cytoplasm. This was shown for the induction of transcription of ferric citrate and pseudobactin-transport genes of Escherichia coli and Pseudomonas putida, respectively (Härle et al., 1995; Koster et al., 1994).

Recently, we identified the $t o n B, \operatorname{exbB}$ and $e x b D 1$ genes of X. campestris pv. campestris, which are essential for ferric iron uptake. In contrast to all bacteria investigated for TonB systems so far, a second exbD gene was identified in X. campestris pv. campestris (Wiggerich et al., 1997). The deduced amino acid sequences of the exbD1 and exbD2 genes showed $38.2 \%$ identity and $71 \cdot 3 \%$ similarity to each other. Interestingly, we were able to show that exbD2 mutants are not impaired in ferric iron uptake. Moreover, the ExbD2 protein cannot substitute the ExbD1 protein in ferric-iron-siderophore uptake (Wiggerich et al., 1997). All four genes, tonB, $\operatorname{exbB}$, exbD1 and exbD2, were found to be clustered in $X$. campestris pv. campestris. Due to low coding probability and the wide spread of translational termination codons in all three reading phases, no other open reading frames were identified downstream of exbD2. Each gene was predicted to have its individual promoter as could be deduced from the analysis of several strains with insertional mutations (Wiggerich $e t$ al., 1997). In the current paper, we report that the ton $B$, $e x b B, e x b D 1$ and $e x b D 2$ genes are necessary for a HR on the nonhost plant pepper.

\section{METHODS}

Bacteria and plasmids. The strains and plasmids used in this work are listed in Table 1.

Media and growth conditions. E. coli strains were grown in Luria broth (LB) medium (Maniatis et al., 1982) at $37^{\circ} \mathrm{C}$. X. campestris pv. campestris strains were grown in tryptoneyeast (TY) medium (Aguilar et al., 1985) at $30^{\circ} \mathrm{C}$. $\mathrm{FeSO}_{4}$ was added to a final concentration of $100 \mu \mathrm{M}$ if needed. Solid media contained agar at $10 \mathrm{~g} \mathrm{l}^{-1}$. Swarm agar plates were made with $0.3 \mathrm{~g} \mathrm{agar}^{-1}$. The final concentrations of antibiotics were: ampicillin (Ap), $200 \mu \mathrm{g} \mathrm{ml}^{-1}$ (E. coli); kanamycin (Km), $50 \mu \mathrm{g} \mathrm{ml}^{-1}$ (X. campestris pv. campestris); gentamicin (Gm), $10 \mu \mathrm{g} \mathrm{ml}^{-1} \quad$ (E. coli) or $30 \mu \mathrm{g} \mathrm{ml}^{-1}$ (X. campestris pv. campestris); and streptomycin (Sm), $800 \mu \mathrm{g} \mathrm{ml}^{-1}$ (X. campestris pv. campestris).

DNA methods, hybridization, transformation and electroporation. Plasmid DNA was isolated using a rapid boiling lysis technique (Arnold \& Pühler, 1988). Total DNA was isolated by lysozyme/sarcosyl/proteinase $\mathrm{K}$ lysis, followed by phenol/chloroform extraction and 2-propanol precipitation (Meade et al., 1982). Restriction enzymes and other commercially available enzymes were obtained from Pharmacia or BRL and used in accordance with the manufacturer's recommendations. Restriction-endonuclease-generated fragments of total DNA were separated by gel electrophoresis and subsequently vacuum blotted on nylon filters as described by Simon et al. (1991). Labelling of the probe (vector and DNA region) and hybridization were done as described elsewhere (Simon et al., 1991). Transformation of E. coli cells and electroporation of $X$. campestris pv. campestris with plasmid DNA were performed as described by Morrison (1977) and Wiggerich et al. (1997), respectively. Agarose gel electrophoresis was carried out as described by Maniatis et al. (1982).

Construction of plasmids. Plasmids pHGW100 and pHGW31 were described previously (Wiggerich et al., 1997). Plasmids pHGW241, pHGW242 and pHGW243 harboured the tonB, exbB and exbD1 gene of $X$. campestris pv. campestris, respectively (Wiggerich et al., 1997). A $1.3 \mathrm{~kb}$ BamHI-XbaI 
Table 1. Bacterial strains and plasmids used in this study

\begin{tabular}{|c|c|c|}
\hline Strain or plasmid & Relevant characteristics & Reference \\
\hline \multicolumn{3}{|l|}{ Strains } \\
\hline \multicolumn{3}{|l|}{ E. coli } \\
\hline 294 & thi pro $h s d R^{-}$, Pro & Bachmann et al. (1976) \\
\hline \multicolumn{3}{|l|}{$\begin{array}{l}\text { Xanthomonas } \\
\text { campestris }\end{array}$} \\
\hline B100 & DSM $1526, \mathrm{Sm}^{\mathrm{r}}$ & Hötte et al. (1990) \\
\hline B100-5.05 & $\operatorname{ton} B$, omegon- $\operatorname{Km}($ cat $)$-induced mutant & Wiggerich et al. (1997) \\
\hline B100-6.01 & omegon- $\operatorname{Km}(c a t)$-induced mutant & Wiggerich et al. (1997) \\
\hline B100-7.03 & $\operatorname{exbB}$, omegon-Km$(c a t)$-induced mutant & Wiggerich et al. (1997) \\
\hline B100-9.01 & exbD1, omegon-Km $(c a t)$-induced mutant & Wiggerich et al. (1997) \\
\hline B100-9.21 & exbD1, aacC1-induced mutant & Wiggerich et al. (1997) \\
\hline B100-11.03 & exbD2, omegon- $\operatorname{Km}(c a t)$-induced mutant & Wiggerich et al. (1997) \\
\hline \multicolumn{3}{|l|}{ Plasmids } \\
\hline pHGW31 & $\begin{array}{l}\text { pHIP1 aacC1 } \triangle B g l \mathrm{II} \text { carrying the multiple } \\
\text { cloning site of pSVB30 }\end{array}$ & Wiggerich et al. (1997) \\
\hline pHGW100 & $\begin{array}{l}\text { pSVB30, Ap }{ }^{\mathrm{r}}, 3.6 \mathrm{~kb} \text { HindIII-SmaI wild-type } \\
\text { fragment }\end{array}$ & Wiggerich et al. (1997) \\
\hline pHGW241 & pHGW31, Gm ${ }^{\mathrm{r}}$, tonB $_{X c c}$ & Wiggerich et al. (1997) \\
\hline pHGW242 & pHGW31, Gm ${ }^{\mathrm{r}}, \operatorname{exb} B_{X c c}$ & Wiggerich et al. (1997) \\
\hline pHGW243 & $\mathrm{pHGW} 31, \mathrm{Gm}^{\mathrm{r}}, \operatorname{exbD} 1_{X c c}$ & Wiggerich et al. (1997) \\
\hline pHGW244 & pHGW31, Gm ${ }^{\mathrm{r}}, \operatorname{exbD2} 2_{X c c}$ & This work \\
\hline
\end{tabular}

(a)

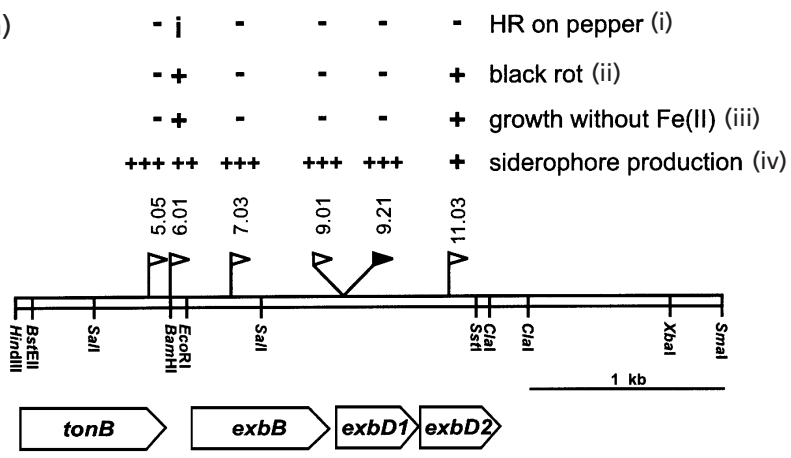

(b)

pHGW244

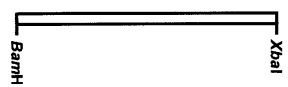

Fig. 1. (a) Genetic and physical map of the $3.6 \mathrm{~kb}$ HindIII-Smal $X$. campestris pv. campestris DNA fragment involved in the uptake of ferric iron. A detailed restriction map is given in Wiggerich et al. (1997). The locations of $\operatorname{ton} B$, exbB, exbD1 and exbD2 are indicated below the restriction map. (b) Subfragment cloned for complementation of the $X$. campestris exbD2 mutant. Open flags indicate the orientation of the cat gene of the omegon-Km(cat) insertions; a filled flag indicates the orientation of the aacC1 gene insertion. (i) +, Typical HR; -, no HR; i, intermediate HR. (ii) +, Typical black rot symptoms;-, single spots of dried leaf tissue. (iii) +, Growth; -, no growth (Wiggerich et al., 1997). (iv) +, Siderophore production; ++ and +++ , enhanced siderophore production (Wiggerich et al., 1997).

subfragment of pHGW100 carrying the exbD2 gene of $X$. campestris pv. campestris resulted from nested deletions with exonuclease III and S1 nuclease (nested deletion kit from
Pharmacia). This $1.3 \mathrm{~kb}$ BamHI-XbaI DNA fragment was cloned into pHGW31 and the resulting plasmid was designated pHGW244 (Fig. 1).

HR test. The HR-inducing ability of $X$. campestris pv. campestris strains was tested on Capsicum annuum cultivars California Wonder, Yolo Wonder and Pusztagold (pepper) as described elsewhere (Arlat et al., 1991; Conrads-Strauch et al., 1990). Seedlings were individually planted into flowerpots filled with sterile vermiculite. Once a week the plants were watered with MS medium (Sigma-Aldrich). After 6 weeks growth in a growth room at $25^{\circ} \mathrm{C}$ and with illumination for $16 \mathrm{~h} \mathrm{~d}^{-1}$ the plants were inoculated by infiltrating approximately $10 \mu$ bacterial culture $\left(1 \times 10^{8}\right.$ cells $\left.\mathrm{ml}^{-1}\right)$ suspended in sterile water into the leaf tissue with a plastic syringe. For the first $2 \mathrm{~d}$ after inoculation the plants were set under high humidity by using closed, transparent chambers. For the rest of the incubation time the plants were maintained under growth room conditions. The growth of bacteria in pepper leaf tissue was studied by infiltrating groups of plants with approximately $100 \mu \mathrm{l}$ of each bacterial suspension containing $10^{7}$ cells $\mathrm{ml}^{-1}$. For a period of $10 \mathrm{~d}$, at $1 \mathrm{~d}$ intervals, $0.95 \mathrm{~cm}^{2}$ discs of infiltrated plant tissue were taken and homogenized in $0.5 \mathrm{ml}$ sterile water. At each time interval discs of five different plants were studied. Suitable dilutions of the homogenates were plated on streptomycin- and kanamycin-supplemented agar. Plates were incubated for $2 \mathrm{~d}$ at $30^{\circ} \mathrm{C}$. Bacterial titres determined were related to $1 \mathrm{~cm}^{2}$ tissue.

Pathogenicity test. Brassica oleracea cultivar Braunschweiger (cauliflower) was used for inoculation of mature host plants. The plants were maintained under growth room conditions described for the HR test. The plants were inoculated by injecting approximately $10 \mu \mathrm{l}$ bacterial culture $\left(1 \times 10^{9}\right.$ cells $\mathrm{ml}^{-1}$ ) suspended in sterile water into the leaf margin. Symptom development was scored for $14 \mathrm{~d}$ after infection. Reisolation of bacteria from cauliflower leaf tissue was carried out as described for pepper. 


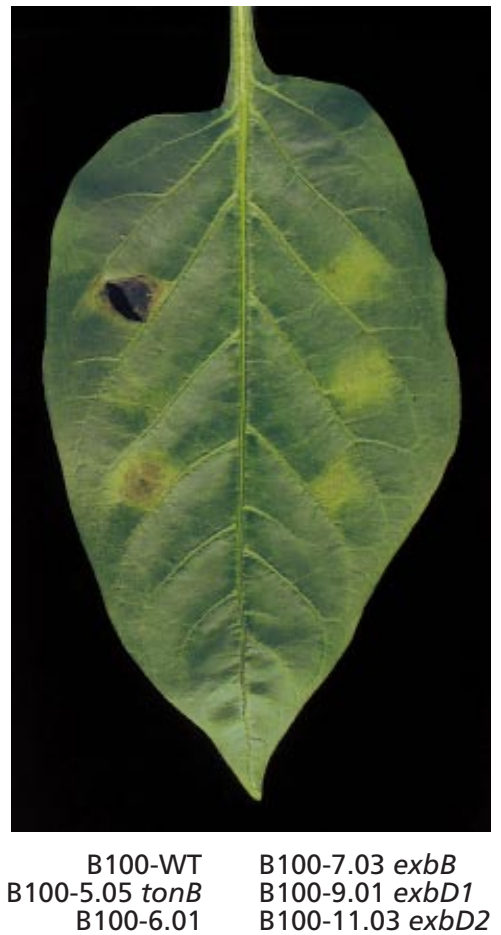

Fig. 2. Symptoms induced in pepper leaves (Capsicum annuum cv. California Wonder) by the wild-type strain $X$. campestris pv. campestris $\mathrm{B} 100$ and its ton $B$, exbB, exbD1 and exbD2 mutants. The ton $B-e x b B$ intergenic mutant B100-6.01 is described in Fig. 1. Approximately $1 \times 10^{6}$ cells suspended in sterile water were infiltrated into the leaf mesophyll tissue with a plastic syringe. Picture of the pepper leaf was taken $4 \mathrm{~d}$ after infiltration.

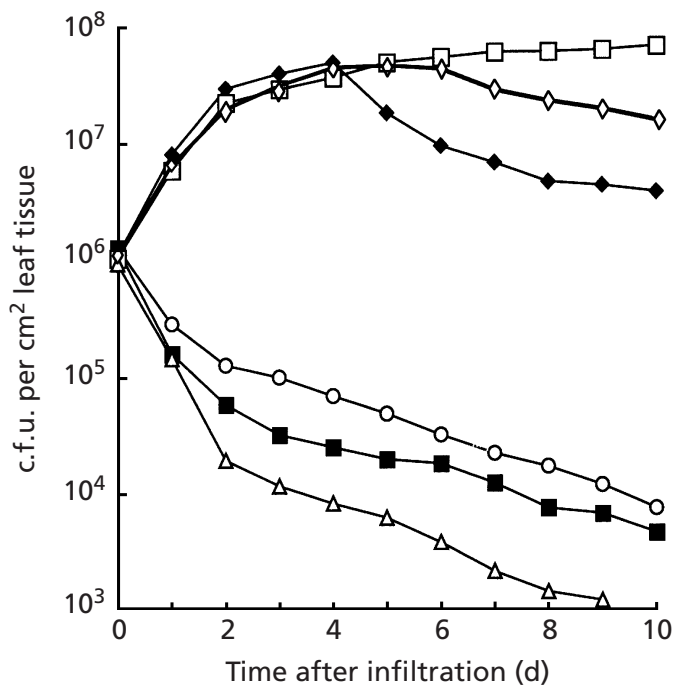

Fig. 3. Viable bacterial titre in planta determined by reisolation of the wild-type strain $X$. campestris pv. campestris B100 and its ton $B$, exbB, exbD1 and exbD2 mutants from infiltrated Capsicum annuum cv. California Wonder (pepper) leaves. $\square$, B100-11.03 (exbD2); $\diamond, \mathrm{B} 100-6.01 ; \diamond, \mathrm{B} 100$ (wt); O, B100-7.03 $($ exbB); 口, B100-9.01 (exbD1); $\triangle, \mathrm{B} 100-5.05$ (tonB). Mutant strain B100-6.01 is described in Fig. 1. Approximately $1 \times 10^{6}$ cells suspended in sterile water were infiltrated into the leaf mesophyll tissue with a plastic syringe. The first value $(0 \mathrm{~d})$ is represented by viable bacterial titre $0.5 \mathrm{~h}$ after infiltration of pepper leaf tissue. The following values were obtained by daily reisolation of bacteria of infected tissue. Each value represents the mean of five samples taken. Data shown represent the results of one out of three independent experiments. Within these experiments, values only differed in a range of $10 \%$.

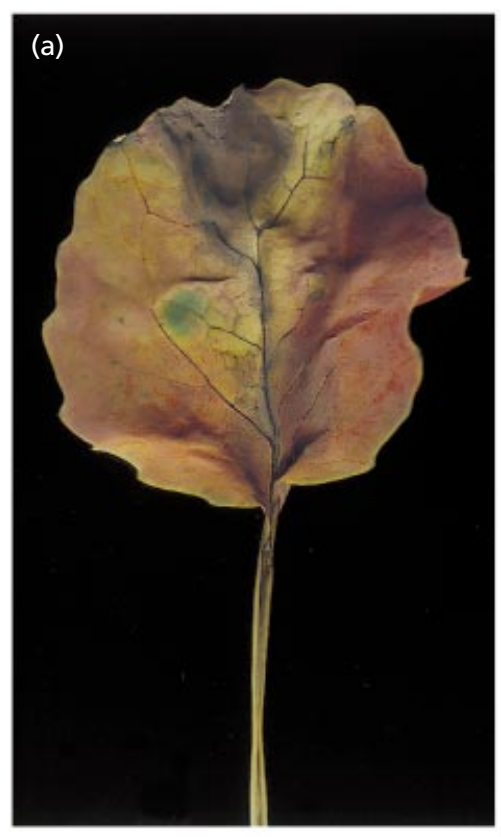

B100-WT

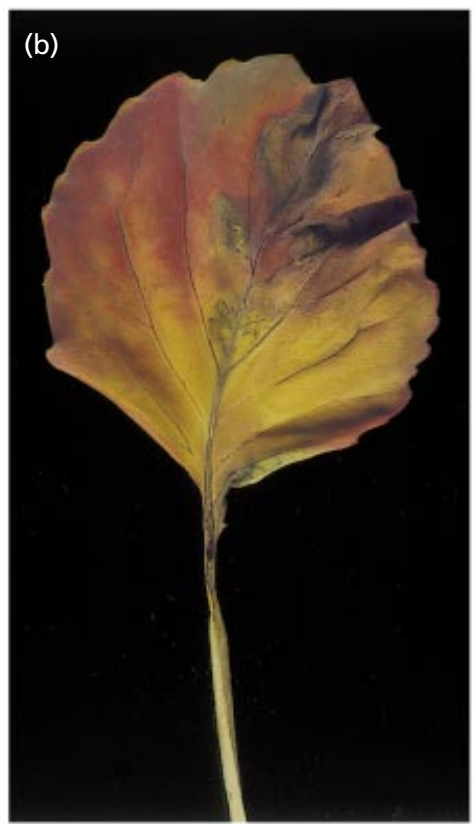

B100-11.03 exbD2

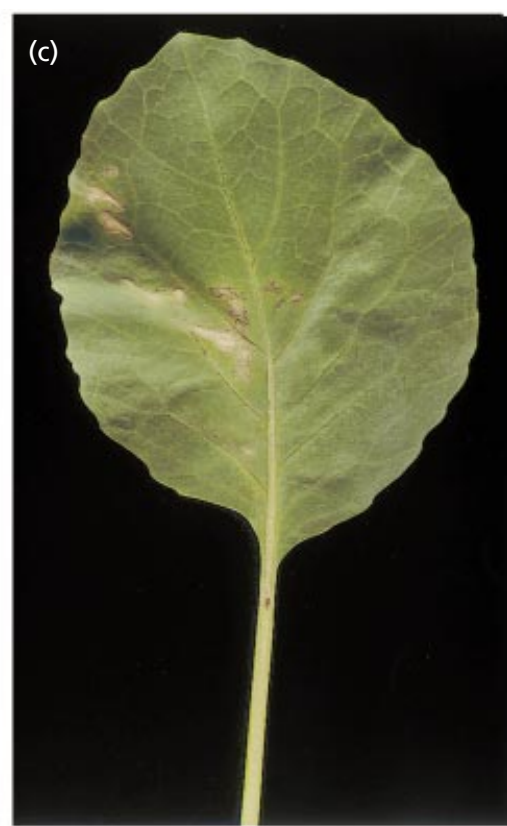

B100-5.05 tonB

Fig. 4. Symptoms evoked by $X$. campestris pv. campestris $\mathrm{B} 100$ (a) and $X$. campestris pv. campestris mutants $\mathrm{B} 100-11.03$ (b) and B100-5.05 (c) on the host plant cauliflower (Brassica oleracea) $14 \mathrm{~d}$ after infection. Suspensions of the bacteria were injected into the petioles at the leaf margins. Whereas $X$. campestris pv. campestris mutant B100-11.03 (b) induced the same symptoms of black rot as the wild-type B100 (a), the $X$. campestris pv. campestris mutant B100-5.05 (c) causes only small spots of dried leaf tissue. 


\section{RESULTS AND DISCUSSION}

\section{$X$. campestris pv. campestris ton $B$, exbB, exbD1 and exbD2 mutants do not elicit a HR on pepper}

Previously, we identified the $\operatorname{ton} B, \operatorname{exbB}, \operatorname{exbD1}$ and exbD2 genes encoding the central structure of the TonB system on a $3.6 \mathrm{~kb}$ HindIII-SmaI DNA fragment of the X. campestris pv. campestris wild-type strain B100 (Fig. 1). Mutations in the $\operatorname{ton} B$, exbB and exbD1 genes, but not in the exbD2 gene, affected ferric iron uptake ex planta (Wiggerich et al., 1997). Since the acquisition of iron is considered to play a crucial role in plantphytopathogen interactions (Expert et al., 1996; Loper \& Buyer, 1991), we analysed whether the tonB/exb gene region also contributes to the induction of a HR on nonhost plants. Therefore, the $X$. campestris pv. campestris mutants B100-5.05 (tonB), B100-7.03 (exbB), B100-9.01 (exbD1), B100-11.03 (exbD2) and B100-6.01 with an omegon- $\mathrm{Km}($ cat $)$ insertion in the intergenic region between ton $B$ and $e x b B$ (Fig. 1) were infiltrated into the leaves of $C$. annumm cv. California Wonder (pepper). The results are presented in Fig. 2. Within $48 \mathrm{~h}$ the HR induced by the wild-type strain $X$. campestris pv. campestris B100 resulted in the formation of typical dark, parchment-like necrotic lesions. The affected dark mesophyll tissue was strictly separated from the unaffected green tissue. In contrast to the $X$. campestris pv. campestris wild-type strain B100, none of the mutant strains induced these typical HR symptoms. Only slight chlorosis occurred in the infected leaf tissue infiltrated with the $\operatorname{ton} B, \operatorname{exbB}$, exbD1 or exbD2 mutants. An HR with strongly reduced symptoms was induced by the intergenic mutant B100-6.01. In this case, the induced HR was characterized by the formation of yellow to brown lesions of the infiltrated mesophyll tissue. The symptoms induced by all mutants mentioned did not develop to wild-type symptoms during longer infection periods (data not shown).

Although typical characteristics of an HR induced by the wild-type strain B100 occurred within $48 \mathrm{~h}$, the photograph presented in Fig. 2 was taken after $96 \mathrm{~h}$ to reach a better differentiation of the symptoms induced by the mutant strains.

The HR-inducing abilities of the mutant strains were also tested on the pepper cultivars Yolo Wonder and Pusztagold. The types of reaction were identical to those with cultivar California Wonder (data not shown).

To confirm that all effects observed were due to the insertions located in the genes investigated, we tested the ton $B, \operatorname{exbB}$, exbD1 and exbD2 mutants complemented with a copy of the particular wild-type gene for their ability to induce an HR. To complement the exbD2 mutant B100-11.03, the suicide vector pHGW244 (exbD2), carrying the corresponding subfragment of the $3.6 \mathrm{~kb}$ HindIII-SmaI wild-type DNA, was constructed and integrated into the genome by a single-crossover event. The correct integration was confirmed by Southern hybridization (data not shown). Mutants B100-5.05::pHGW241 (tonB), B100-7.03::pHGW242 $(e x b B)$ and B100-9.01::pHGW243 (exbD1) were described previously (Wiggerich et al., 1997). Each merodiploid mutant regained the ability to induce wild-type HR symptoms when infiltrated into pepper leaves. However, symptom formation was delayed by $2 \mathrm{~d}$.

To rule out the possibility that the inability of the exbD1 mutant B100-9.01 to induce an HR was due to the lack of both ExbD1 and ExbD2 proteins, we tested strain B100-9.21 carrying an $a a c C 1$ gene in the exbD1 gene bringing the exbD2 gene under the control of the constitutively active $\mathrm{P}_{\text {out }}$ promoter of the aacC1 gene (Wiggerich et al., 1997). Like strain B100-9.01 mutant strain B100-9.21 induced only slight chlorosis in the infected leaf tissue (data not shown).

\section{The $X$. campestris pv. campestris ton $B$, exbB and exbD1 mutants died rapidly, but the exbD2 mutant grew even better than the wild-type strain in pepper leaf tissue}

As has been shown previously, the TonB system of $X$. campestris pv. campestris is involved in ferric iron uptake explanta (Wiggerich et al., 1997). Therefore, the investigated mutant strains could have failed to acquire iron in planta, resulting in a lack of growth. To analyse if this was the reason why the tonB/exbBD1D2 mutant strains failed to induce an HR on pepper we scored the viable bacteria by reisolation from infiltrated pepper leaf tissue for the first $2 \mathrm{~d}$ after infection (Fig. 3). Surprisingly, the mutants behaved differently. During the first $4 \mathrm{~d}$ after infiltration the bacterial titre of the wild-type strain B100 increased from $1 \times 10^{6}$ bacteria initially infiltrated to $7 \times 10^{7}$ bacteria per $\mathrm{cm}^{2}$ tissue. As expected, within the next $4 \mathrm{~d}$, the bacterial titre decreased rapidly to a value of $5 \times 10^{6}$ cells per $\mathrm{cm}^{2}$. In contrast, the viable bacterial titre of the mutant strains B100-5.05 (tonB), B100-7.03 (exbB) and B100-9.01 (exbD1) decreased immediately after infiltration from a value of $1 \times 10^{6}$ bacteria per $\mathrm{cm}^{2}$ tissue to values two to three orders of magnitude lower. Not only were these mutants unable to grow in the pepper leaf tissue, they even died rapidly. Since these mutant strains were also found to grow only on medium supplemented with ferrous iron (Wiggerich et al., 1997), they were considered to be unable to acquire iron in planta, thus explaining the absence of growth. The decreasing number of bacteria seems to be the reason that pepper did not establish an HR. An unexpected result was obtained with the exbD2 mutant B100-11.03. The bacterial titre of this mutant strain increased during the first $4 \mathrm{~d}$ after infiltration, as did the titre of the wild-type strain. However, in contrast to the viable bacterial titre of the wild-type strain B100, the bacterial titre of the exbD2 mutant B100-11.03 did not decrease at all. Instead, the bacteria multiplied to a titre of $9 \times 10^{7}$ cells per $\mathrm{cm}^{2}$ during the following $6 \mathrm{~d}$. Similarly to the ex planta state (Wiggerich et al., 1997), this mutant was probably able to acquire iron in planta. Interestingly, despite its higher titre, the exbD2 mutant strain did not induce HR symptoms on pepper, indicating the dis- 
turbance of the interaction between this mutant and the nonhost plant pepper. The bacterial titre of the intergenic mutant B100-6.01 increased during the first $5 \mathrm{~d}$ to $5 \times 10^{7}$ bacteria per $\mathrm{cm}^{2}$ tissue, then decreased to a value of $2 \times 10^{7}$ bacteria per $\mathrm{cm}^{2}$ tissue. The intergenic mutant B100-6.01, which is not affected in iron import (Wiggerich et al., 1997), induced an HR with strongly reduced symptom formation. In accordance we found that this strain could multiply for a longer period of time in infected pepper leaf tissue than the wild-type strain. However, even this reduced HR led to a decreasing number of viable bacteria. Although the insertional mutation in strain B100-6.01 is intergenic, this mutation affected the interaction between this mutant strain and pepper. A reason for this effect can be the disturbance of a common regulation of the tonB/exbBD1D2 genes. Since the complemented mutant strains were in a merodiploid state, this regulation may also be affected in the complemented strains, resulting in a delay of symptom formation of $2 \mathrm{~d}$. We conclude that the recognition between $X$. campestris pv. campestris and its nonhost plant pepper is disturbed in mutant strains with an ineffective TonB system independently of their capacity to import iron.

It appeared that the wild-type strain B100 and all mutant strains were restricted to the infiltrated tissue.

The production of ferric-siderophores has been suggested as an elicitor of plant defence reactions (Expert et al., 1996). Chrysobactin, a siderophore produced by E. chrysanthemi, has been identified as a virulence factor in plant disease (Enard et al., 1988). Since the $X$. campestris pv. campestris ton $B$, exbB and exbD1 mutant strains exhibited an increased siderophore production (Wiggerich et al., 1997), the siderophore of $X$. campestris pv. campestris cannot be the elicitor of HR induction in pepper. Additional work is necessary to determine whether signal molecules are recognized or imported via the TonB system in $X$. campestris pv. campestris.

\section{The $X$. campestris pv. campestris exbD2 mutant, but not the ton $B$, exbB and exbD1 mutants, induced typical black rot symptoms on the host plant cauliflower}

Since the exbD2 mutant strain B100-11.03 was able to grow in pepper, we wanted to know whether this strain was also affected in the interaction with host plants. Therefore, the $\operatorname{ton} B, \operatorname{exbB}$, exbD1 and exbD2 mutant strains and the wild-type strain B100 were injected into leaf margins of $B$. oleracea (cauliflower). Symptoms caused by the wild-type strain were blackening of the leaf veins followed by sectorial drying and death of the leaf tissue (Fig. 4a). The iron-uptake genes tonB, exbB and exbD1 are therefore not only necessary for the interaction with nonhost plants but also with the host plant cauliflower, because strains carrying a mutation in one of these genes no longer induced the typical black rot symptoms. Since the sectorial drying of the leaf tissue is missing, the blockage of veins, which is commonly considered to be the reason for death of leaf tissue, did not occur. The symptoms caused by the exbD2 mutant strain were identical to those induced by the wild-type strain (Fig. 4b). Only a slight delay of symptom formation during the first $2 \mathrm{~d}$ after injection could be detected (data not shown).

Interestingly, the ton $B, \operatorname{exb} B$ and $e x b D 1$ mutants caused symptoms which were completely different from those observed for the wild-type strain. In all leaves infected with the mutant strains blackening of the veins did not occur, even after $14 \mathrm{~d}$ following infection. Also sectorial drying of the leaf tissue was missing. Instead, small single spots of dried leaf tissue occurred on parts of the leaf, as shown in Fig. 4(c) for the tonB mutant strain B100-5.05. Reisolation experiments revealed that the ton $B, \operatorname{exbB}$, exbD1 and exbD2 mutants and the wildtype strain had spread systemically over the whole leaves (data not shown). This means that they can multiply in B. oleracea. Therefore, these strains had to be able to utilize ferrous iron provided by the host plant.

\section{The exbD2 gene of $X$. campestris pv. campestris increases the known scope of the TonB system function}

The TonB system of Gram-negative bacteria is not only involved in ferric-iron-siderophore uptake but also serves as the central structure of the import pathways of several macromolecules (Postle, 1990; Braun, 1995). Moreover, the TonB system and related components normally used for iron uptake were shown to mediate the induction of transcription of ferric citrate and pseudobactin transport genes from the cell surface in $E$. coli and P.putida, respectively (Härle et al., 1995; Koster et al., 1994). In X. campestris pv. campestris, a second ExbD protein (ExbD2) is present, which cannot substitute for the ExbD1 protein in ferric iron uptake (Wiggerich et al., 1997). We have demonstrated here that this ExbD2 protein was found to be involved in the induction of an HR in pepper. To our knowledge, the existence of a second ExbD protein has not been reported for other Gram-negative bacteria so far. With respect to the results published here it would be interesting to know whether a second exbD2 gene is present in other HR-inducing bacteria. Mutational analysis revealed that although the ton $B, \operatorname{exbB}$, exbD1 and exbD2 genes are likely to form one operon, the exbD1 and exbD2 genes can be independently expressed from the tonB and exbB genes (Wiggerich et al., 1997). Since tonB, exbB and exbD1 mutant strains, like the exbD2 mutant strain, were unable to induce an HR on pepper, one can speculate that the ExbD2 protein interacts with the central structure of the TonB system, consisting of the TonB, ExbB and ExbD1 proteins, to increase the scope of the TonB system. Further investigations of the TonB system might give new insights into the signal exchange between phytopathogenic bacteria and plants. 


\section{ACKNOWLEDGEMENTS}

This work was financially supported by the Deutsche Forschungsgemeinschaft, Sonderforschungsbereich 223 and 549.

\section{REFERENCES}

Aguilar, O. M., Kapp, D. \& Pühler, A. (1985). Characterization of a Rhizobium meliloti fixation gene $(\mathrm{fix} F)$ located near the common nodulation region. J Bacteriol 164, 245-254.

Arlat, M., Gough, C. L., Barber, C. E., Boucher, C. \& Daniels, M. J. (1991). Xanthomonas campestris contains a cluster of hrp genes related to the larger hrp cluster of Pseudomonas solanacearum. Mol Plant-Microbe Interact 4, 593-601.

Arlat, M., Van Gijsegem, F., Huet, J. C., Pernollet, J. C. \& Boucher, C. A. (1994). PopA1, a protein which induces a hypersensitive-like response on specific Petunia genotypes, is secreted via the Hrp pathway of Pseudomonas solanacearum. EMBO J 13, 543-553.

Arnold, W. \& Pühler, A. (1988). A family of high copy-number plasmid vectors with single end-label sites for rapid nucleotide sequencing. Gene 70, 171-179.

Bachmann, K., Patschne, M. \& Gilbert, W. (1976). Construction of plasmids carrying the CI gene of bacteriophage $\lambda$. Proc Natl Acad Sci USA 73, 4174-4178.

Bonas, U. (1994). hrp genes of phytopathogenic bacteria. Curr Top Microbiol Immunol 192, 79-98.

Bradbeer, C. (1993). The proton motive force drives the outer membrane transport of cobalamin in Escherichia coli. J Bacteriol 175, 3146-3150.

Braun, V. (1995). Energy-coupled transport and signal transduction through the gram-negative outer membrane via TonBExbB-ExbD-dependent receptor proteins. FEMS Microbiol Rev 16, 295-307.

Conrads-Strauch, J., Dow, J. M., Milligan, D. E., Parra, R. \& Daniels, M. J. (1990). Induction of hydrolytic enzymes in Brassica campestris in response to pathovars of Xanthomonas campestris. Plant Physiol 93, 238-243.

Dangl, J. L. (1994). The enigmatic avirulence genes of phytopathogenic bacteria. Curr Top Microbiol Immunol 192, 99-118.

Daniels, M. J., Barber, C. E., Dow, J. M., Han, B., Liddel, S. A., Newman, M. A., Parker, J. E., Soby, S. D. \& Wilson, T. G. J. (1992). Plant and bacterial genes involved in interactions between Xanthomonas and crucifers. In Advances in Molecular Genetics of Plant-Microbe Interactions, pp. 423-433. Edited by E. W. Nester \& D. P. S. Verma. Dordrecht: Kluwer.

Dow, J. M. \& Daniels, M. J. (1994). Pathogenicity determinants and global regulation of pathogenicity of Xanthomonas campestris pv. campestris. Curr Top Microbiol Immunol 192, 29-41.

Enard, C., Diolez, A. \& Expert, D. (1988). Systemic virulence of Erwinia chrysanthemi 3937 requires a functional iron assimilation system. J Bacteriol 170, 2419-2426.

Expert, D., Enard, C. \& Masclaux, C. (1996). The role of iron in plant host-pathogen interactions. Trends Microbiol 4, 232-237.

Fenselau, S. \& Bonas, U. (1995). Sequence and expression analysis of the hrpB pathogenicity operon of Xanthomonas campestris pv. vesicatoria which encodes eight proteins with similarity to components of the Hrp, Ysc, Spa, and Fli secretion system. Mol Plant-Microbe Interact 8, 845-854.

Fenselau, S., Balbo, I. \& Bonas, U. (1992). Determinants of pathogenicity in Xanthomonas campestris pv. vesicatoria are related to proteins involved in secretion in bacterial pathogens of animals. Mol Plant-Microbe Interact 5, 390-396.

Härle, C., Kim, I., Angerer, A. \& Braun, V. (1995). Signal transfer through three compartments: transcription initiation of the Escherichia coli ferric citrate transport system from the cell surface. EMBO J 145, 1430-1438.

He, S. Y., Huang, H. C. \& Collmer, A. (1993). Pseudomonas syringae pv. syringae harpin $\mathrm{Pss}_{\text {: }}$ a protein that is secreted via the Hrp pathway and elicits the hypersensitive response in plants. Cell 73, 1255-1266.

Hötte, B., Rath-Arnold, I., Pühler, A. \& Simon, R. (1990). Cloning and analysis of a 35.3-kilobase DNA region involved in exopolysaccharide production by Xanthomonas campestris pv. campestris. J Bacteriol 172, 2804-2807.

Klement, Z. (1982). Hypersensitivity. In Phytopathogenic Prokaryotes, pp. 149-177. Edited by M. S. Mount \& G. H. Lacy. New York: Academic Press.

Koster, M., van Klompenburg, W., Bitter, W., Leong, J. \& Weisbeck, P. (1994). Role for the outer membrane ferric siderophore receptor PupB in signal transduction across the bacterial cell envelope. EMBO J 13, 2805-2813.

Loper, J. E. \& Buyer, J. S. (1991). Siderophores in microbial interactions on plant surfaces. Mol Plant-Microbe Interact 4, $5-13$.

Maniatis, T., Fritsch, E. F. \& Sambrook, J. (1982). Molecular Cloning: a Laboratory Manual. Cold Spring Harbor, NY: Cold Spring Harbor Laboratory.

Meade, H., Long, S., Ruvkun, G., Brown, S. \& Ausubel, F. (1982). Physical and genetic characterization of symbiotic and auxotrophic mutants of Rhizobium meliloti induced by transposon Tn5 mutagenesis. J Bacteriol 149, 114-122.

Morrison, D. A. (1977). Transformation in E. coli: cryogenic preservation of competent cells. J Bacteriol 132, 349-351.

Postle, K. (1990). TonB and the gram-negative dilemma. Mol Microbiol 4, 2019-2025.

Raymond, K. N., Müller, G. I. \& Matzanke, B. F. (1989). Complexation of iron by siderophores. A review of their solution and structural chemistry and biological function. Top Curr Chem 123, 49-58.

Ritter, C. \& Dangl, J. L. (1995). The avrRpm1 gene of Pseudomonas syringae pv. maculicola is required for virulence on Arabidopsis. Mol Plant-Microbe Interact 8, 444-453.

Simon, R., Hötte, B., Klauke, B. \& Kosier, B. (1991). Isolation and characterization of insertion sequence elements from Gramnegative bacteria using new broad-host-range, positive selection vectors. J Bacteriol 173, 1502-1508.

Sutherland, I. W. (1993). Xanthan. In Xanthomonas, pp. 363-388. Edited by J. G. Swings \& E. L. Civerolo. London: Chapman \& Hall.

Swings, J. G. \& Civerolo, E. L. (1993). Xanthomonas. London: Chapman \& Hall.

Van den Ackerveken, G., Marois, E. \& Bonas, U. (1996). Recognition of the bacterial avirulence protein AvrBs3 occurs inside the host plant cell. Cell 87, 1307-1316.

Wei, Z.-M., Laby, R. J., Zumoff, C. H., Bauer, D. W., He, S. Y., Collmer, A. C. \& Beer, S. V. (1992). Harpin, elicitor of the hypersensitive response produced by the plant pathogen Erwinia amylovora. Science 257, 85-88.

Wengelnik, K., Marie, C., Russel, M. \& Bonas, U. (1996). Expression and localization of HrpA1, a protein of Xanthomonas 
campestris pv. vesicatoria essential for pathogenicity and induction of the hypersensitive reaction. J Bacteriol 178, 1061-1069.

Wiggerich, H. G., Klauke, B., Köplin, R., Priefer, U. B. \& Pühler, A. (1997). Unusual structure of the tonB-exb DNA region of Xanthomonas campestris pv. campestris: ton $B, \operatorname{exbB}$, and exbD1 are essential for ferric iron uptake, but exbD2 is not. $J$ Bacteriol 179, 7103-7110.

Williams, P. H. (1980). Black rot, a continuing threat to world crucifers. Plant Dis 64, 736-742.
Willis, D. K., Rich, J. J. \& Hrabak, E. M. (1991). hrp genes of phytopathogenic bacteria. Mol Plant-Microbe Interact 4, $132-138$.

Yang, Y. \& Gabriel, D. W. (1995). Xanthomonas avirulence/ pathogenicity gene family encodes functional plant nuclear targeting signals. Mol Plant-Microbe Interact 8, 627-631.

Received 6 January 2000; accepted 31 January 2000. 